\title{
Urban Advantage? Sustainable Consumption and Ontological Cityism Across the Urban Hierarchy
}

\author{
Lin Lerpold and Örjan Sjöberg
}

\begin{abstract}
SetTing The Scene
Campbell's (1996) influential thoughts on "green cities, growing cities, just cities" have been lauded for their clarity on the trade-offs inherent in any project of sustainable urban development and "plac[ing] the power relations of a capitalist society front and center" (Miller, 2015, 109). Yet his " 3 Es" of ecology, economy and equity have been criticised for being too limited (e.g. Godschalk, 2004; Hirt, 2016), that it risks turning growth into an end rather than a means (Næss, 2001), and that it indeed
\end{abstract}

\section{Lerpold $(\bowtie)$}

Center for Sustainability Research, Department of Marketing and Strategy, Stockholm School of Economics, Stockholm, Sweden

e-mail: Lin.Lerpold@hhs.se

Ö. Sjöberg

Center for Sustainability Research,

Stockholm School of Economics, Stockholm, Sweden

e-mail: Orjan.Sjoberg@hhs.se

(C) The Author(s) 2021

R. Bali Swain and S. Sweet (eds.), Sustainable Consumption and

Production, Volume I, https://doi.org/10.1007/978-3-030-56371-4_14 
"remains firmly grounded within the structures and resource allocation mechanisms of late capitalism" (Miller, 2015, 110).

However, its core question, "what should we sustain?" (Campbell, $2016,390)$, is as relevant as ever. It highlights the conflicts inherent in pursuing different sustainability goals and the inevitable futility of trying to reach that elusive sweet spot of an optimal outcome-without giving up on the all-important quest of getting there. The fact that the urban planner's triangle has a counterpart in Barbier's $(1987,104)$ three intersecting circles of biological, economic and social systems goalstoday typically styled as environmental, economic and social sustainability, respectively - that offer a similar level of conceptual clarity and still more effective visual communication, does not make the truly sustainable any less elusive.

Also disregarding the recent observation by Purvis, Mao, and Robinson (2019) to the effect that the three pillars of sustainability appear to lack a properly worked out theoretical rationale, at least in part this elusiveness stems not only from the need to compromise across objectives, but also the slipperiness of language. Sustainability, as used in politics and academic writings alike, is at once both an absolute state and a process, at times a promise of moving in the direction of the fully sustainable. However, as Rees $(2012,247)$ has noted, "modern cities as presently conceived are inherently unsustainable", an observation that runs up against the parallel claim that economic progress is linked to the superior productivity of the most densely settled points in geographical space (Glaeser, 2011; Jacobs, 1969). The urban agglomeration's importance to economic growth, in turn seen as a necessary condition for achieving socially equitable outcomes ("the big dilemma" as Haavelmo \& Hansen, 1992 style it), works against any reconsideration of the role, nature and impact of urban consumption and production, no matter how desirable such a rethinking might be.

Thus, even as we will fall seriously short of reversing the laws of thermodynamics on which Rees (2012) builds his argument, or achieving any form of a "misty-eyed vision of a peaceful ecotopia" (Campbell, 1996, 297), if we are to make our cities and towns more sustainable we need to assess the sustainability dimensions of urban living, including the consumption and production that goes with it. This chapter and the companion one that follows address these issues-the one setting sight on sustainability outcomes across systems of urban centres and the complexities of drawing boundaries for assessment, and the other 
(Lerpold, Sjöberg, \& Tang, 2020) focusing on the intra-urban dimension and trade-offs between the 3 Es of it all. As we start with the inter-urban dimension, the consequences of positive agglomeration effects would appear to favour larger and more densely built urban environments over those that are smaller and are less effective in making use of the space at hand. However, this conclusion is not as straightforwardly simple or self-evident as it might seem. The very notion of the city, its boundaries and its impacts within and beyond those boundaries weigh in on that.

\section{Achieving Sustainability: Urban Advantage?}

In the popularising literature à la Jacobs or Glaeser, high density and proximity are identified as a major source of benefits, including with respect to resource use. From the pioneering work of Marshall (1890: $\mathrm{Bk} 4$, Chapter 10) onwards, this is an idea that has found much favour in the specialist literature in urban economics and economic geography (Combes \& Gobillon, 2015; Glaeser \& Gottlieb, 2009; Hanson, 2001; Hoover, 1937; Puga, 2010; Rigby \& Essletzbichler, 2002; Scott \& Storper, 2014; Storper \& Venables, 2004; Sveikauskas, 1975). Cities allow for a number of agglomeration advantages such as more efficient labour markets, greater innovative capacity and related expressions of superior knowledge exchange; additionally, suppliers (e.g. of producer services) are more likely to be readily at hand. Such positive externalities enhance capacity utilisation and reduce the cost per unit of production. Sustainability scholars often share similar sentiments, and for a reason (Satterthwaite, 1997). Not only do new approaches to urban design "hold promise for a significant reduction in environmental impact" (Newton, 2011 , 1; also e.g. Joss et al., 2015; Larco, 2016), on a priori grounds we may also expect that cities as they exist have a number of advantages that make them more "efficient" from a sustainability point of view than less densely populated places.

The most prominent of these advantages allowing for a relative decoupling of growth and environmental impacts relate to the use of space-less land per capita - and to the lower cost of supplying physical infrastructure in transportation, energy, water and sewage. Hence, investment in systems that enhance sustainability become a more attractive proposition, all else equal. Furthermore, material recycling might be more effectively promoted-the waste heat of one activity for instance, might become an input to another. Public transport makes more economic and practical 
sense while walking or biking as mobility options are likely to be facilitated. High density and a large population also combine to make the sharing economy, however conceptualised, a more practical proposition.

Yet a priori expectations do not necessarily translate into unambiguous outcomes on the ground. Empirical results do, however, suggest that productivity and income vary with density or the size of towns and cities, the functional regions they are part of (e.g. labour market regions as delineated by commuting patterns) or the degree of market access, and do so in a systematic fashion that favours larger centres over smaller ones (Bolton \& Breau, 2012; Fallah, Partridge, \& Olfert, 2011; Korpi, 2008; Wheeler, 2004). Indeed, rapidly expanding literature on spatial sorting offers indirect support for the idea that in terms of efficiency, the larger the better (e.g. Eeckhout, Pinheiro, \& Schmidheiny, 2014; Glaeser \& Resseger, 2010; Glaeser, Resseger, \& Tobio, 2009; Mion \& Naticchioni, 2009; Venables, 2011; Wheeler, 2001). While this literature points in the direction of the need to take differences in education, labour market experience, size of employing organisation and a host of similar factors into account when urban sustainability is assessed, it can be thought of as reflecting the benefits to be gained from increasing size and density. ${ }^{1}$

However, to substantiate the claim with respect to sustainability that the larger and the denser the better, we need to assess empirical results as they exist. Although there is a wide range of studies representing a variety of traditions, not all of which are immediately comparable with respect to scope and outcomes, the inter-urban perspective allows us the privilege of setting out from one standard approach that provides for assessments that often can be compared across samples and settings. This is the use of power or scaling laws, which affords a benchmark against which outcomes in the form of elasticities can be compared across city sizes in an entire urban system. As will become apparent, however, and in spite of claims that such approaches can be extended to a "unified theory of urban living" (Bettencourt \& West, 2010), it runs up against a number of problems that may serve to undermine the seemingly straightforward empirical observations and conclusions that appear to follow. Seen from a sustainability point of view, glitches as they exist, turn out to be of some consequence. 


\section{Not in Isolation: The Fallacy of Ontological Cityism}

A significant issue in discussing whether urban areas are more or less sustainable than rural ones, is how sustainability is assessed or, more specifically, where the boundaries are drawn for assessment. Popular frameworks within sustainability assessment such as Life Cycle Analysis, Cradle-to-Cradle and Circular Economy have significantly influenced how we measure sustainability impacts by a product or service's life from inception to recycling. Thus, rather than the spatial dimension of consumption impacts within a geographically bounded area as a determinant of measurement, boundaries are instead drawn along the whole life cycle of a product and service irrespective of where they are spatially incurred. For instance, combining the post-Westphalian nation-state world order with global climate change concerns has resulted in so-called "methodological nationalism" (Wimmer \& Glick Schiller, 2002), whereby carbon footprints $(\mathrm{CF})$ are measured nation-wise, for instance where the $\mathrm{CO}_{2}$ emissions are produced or where they are consumed as separate accounts. Though most developed nations have greened their own economies by moving production, they have offshored much of their own consumption emissions to developing nations where the emissions are incurred and measured. The non-profit Global Footprint Network has long brought this issue to the fore where per capita footprints based on consumption have shown how the rich, per capita, are responsible out of proportion for worldwide emissions. The recognition of this measurement issue can also be understood in the UN Paris Climate Accord (2015) where the developed nations promised economic assistance to developing nations to support developing nations' climate action work, including the recent COP 25 meeting in Madrid (2019) which was considered by most to have failed because of measurement controversy between states. The complexity of measurement beyond and between nations has also found increasing national support, as can be seen for example in Sweden's first official statistics within the environmental accounts framework (SCB, 2019), where the environmental pressure due to the production and consumption of goods and services by industry, households and the public sector in Sweden and abroad are included.

The failure to consider such effects beyond the city limits can be thought of as a case of "ontological cityism". Not to be confused with the kindred notion of "methodological cityism" used as a means to critique 
the "near-exclusive analytical lens for studying contemporary processes of urban social transformation that are not limited to the city" (Angelo \& Wachsmuth, 2015, 20) said to prevail in urban political economy, we are instead concerned with the arbitrary empirical assessment of sustainability impacts within and across individual urban, and urban and rural, boundaries. To illustrate, using life cycle or an extended value chain assessment of environmental impacts, though emissions within the city limits from electric vehicles or biofuel buses may seem low, the emissions of the production of the vehicles, especially if produced with coal-based energy in a more peripheral or offshore manufacturing area, may be very high. Moreover, there are trade-offs between emissions within city boundaries and other negative externalities in production along the extended value chain of, for instance, electric buses versus diesel buses from the effects of battery production significant to global warming, carcinogens, ozone depletion and eco-toxicity (Cooney, Hawkins, \& Marriott, 2013). Thus, as production has moved down the urban hierarchy-a form of spatial "settlement-size, industrial sorting process" (Moriarty, 1991, 1573), well known to economic geographers-or simply been shifted abroad, local consumption levels may not have been similarly affected. On the contrary, both continued demographic urbanisation and spatial sorting by education and incomes suggest that the issue of measuring impacts beyond the city gates has become increasingly salient. In the same way as production and consumption are geographically decoupled and go beyond national or city borders, so too does ontological cityism serve to camouflage the impacts between and within the rural and the urban, indeed across different tiers of the urban hierarchy.

\section{Perhaps Not Parasitic, but Do Urbanites Consume More Than Others?}

While Jacobs (1969) may have proposed, wrongly, that urban areas once gave rise to agriculture rather than the other way around, at least since the ancient Greek writer and poet Hesiod it has often been held that urban settlements lived off the surrounding countryside. Today, the dominant view is that instead of being parasitic, it is a symbiotic relationship: the one presupposes the other. Indeed, the distinction between rural and urban, although still meaningful to many, has been argued to be of little analytical utility (e.g. Dymitrow \& Brauer, 2018; Thisse, 2014). This might be so, 
but the higher level of incomes characteristic of settlements at the upper tiers of the urban hierarchy do potentially make a difference.

Thus, early on the originators of the notion of ecological footprints applied it to modern cities (Rees, 1992; Rees \& Wackernagel, 1996). Translating the national average per capita footprint to its urban equivalent of course puts the area "appropriated" in stark contrast to that actually occupied by any given city. Mere density will see to that, but it says little about whether the per capita imprint would be greater or smaller than for the same population dispersed over wider areas. In other words, that observation does not allow us to draw the conclusion that it is the quality of being urban itself that results in a larger footprint than that generated by non-urban areas.

On the contrary, as noted in the previous section, a substantial body of research indicates that cities have a distinct advantage from a sustainability point of view compared to less densely organised forms of human activities. Bettencourt and West $(2010,912)$ thus suggest that

doubling the population of any city requires only about an $85 \%$ increase in infrastructure, whether that be total road surface, length of electrical cables, water pipes or number of petrol stations. This systematic $15 \%$ savings happens because, in general, creating and operating the same infrastructure at higher densities is more efficient, more economically viable, and often leads to higher-quality services and solutions that are impossible in smaller places. Interestingly, there are similar savings in carbon footprints-most large, developed cities are 'greener' than their national average in terms of per capita carbon emissions.

In short, "[b]igger cities do more with less" (Bettencourt \& West, 2011, 44). Claims like these issue from the literature on urban scaling. It helps shed some light on how size and sustainability impacts correlate. Although short on explanations except at the most general level (Pumain, 2012; Pumain, Paulus, Vacchiani-Marcuzzo, \& Lobo, 2006)—it puts things down to complexity and self-organisation (Bettencourt, 2013) any systematic deviation from pure allometric growth of population or other urban indicators can be taken as a sign of increasing or decreasing returns to urban scale (Batty, 2013, 38-43; Nordbeck, 1971). If elasticities are above 1 (often labelled super-linearity), we will have decreasing returns to scale: resource use expands at a higher rate than does population growth. Conversely, elasticities below l (sub-linearity) are indicative 
of economies of scale in resource use and the savings mentioned in the quote above are a tangible result of such processes.

According to research in this tradition, the provision of infrastructure, energy use, pollution and a host of related indicators are observed to display such sub-linear scaling (Bettencourt, Lobo, Helbing, Kühnert, \& West, 2007; Facchini, Kennedy, Stewart, \& Mele, 2017; Louf, Roth, \& Barthélémy, 2014; Zheng, de Beurs, Owsley, \& Henebry, 2019), implying lower use per capita as size increases. Part of a pattern and set of principles that stretch far beyond the study of the urban (e.g. West, 2017), positive agglomeration effects thus help us economise on resources and we would be better off concentrating activities to a greater extent than is typically the case today. As such, the urban environmental footprint might increase, but as assessed on a per capita basis across a full urban system or national economy, the change is beneficial as less is needed to sustain the population at a given level of consumption.

Results like these have not gone unchallenged and it is not only a clash between those who think in terms of relative improvements and those who maintain that sustainability is an absolute entity that requires more than mere tinkering at the margin. This is so as a lower level of resource use per capita at a given point in time does not necessarily imply less consumption in the aggregate or as assessed over time. The critique can essentially be summarised by a few observations. First, as already noted, urban resource use often overlooks the urban areas' use of resources beyond the confines of the city itself (e.g. Seto et al., 2012). Making use of "functional cities" (i.e. delineating the urban territory on functional rather than administrative grounds) as Bettencourt and Lobo (2016) propose might represent an improvement but does not solve the underlying problem. Second, the qualitative nature of that resource use may differ across settlement sizes in systematic ways, as has been documented with respect to the stocks and flows of building materials (Gontia, Thuvander, \& Wallbaum, 2020). Third, the higher incomes that higher productivity is likely to generate do not go unused. While some of the higher incomes are likely to be absorbed by the higher cost of housing that more expensive land implies, there is still a distinct possibility that higher incomes also translate into higher levels of consumption. (And they do translate into higher rents for some people.) Fourth, the very fact that urban areas are diverse should be taken into account, in particular if they differ systematically across the urban hierarchy (for instance because of a division of labour along the lines of comparative advantage). 
Hence, or so Thisse $(2014,807)$ argues, the idea of cities being "scaled versions of one another" sits uneasily with the common observation that cities differ among themselves. As it happens, so formulated, this final piece of critique does not quite hit its target, as also those in favour of an allometric approach to urban growth are often clear about the qualitative changes that come with increased size (e.g. Batty 2018: Chapter 4; Youn et al., 2016). It is rather, in addition to finding those indicators that do actually scale linearly with urban size and those that do not (Arcaute et al., 2015), an issue of identifying causality and attributing it properly.

These three lines of critique all contain arguments of principle (e.g. that city size is an endogenous variable as people are attracted by the higher incomes, a division of labour across urban centres implies differences in the structure of production), but empirically the results can often go both ways. Therefore, we should take care not to draw wide-ranging conclusions from case studies or research on individual city systems. Yet some problems are quite common. Thus, as for the first point, studies using scaling laws almost invariably only account for local resource use and do so for the most practical of reasons: data availability. One of few studies that does not so confine itself, is a study of the water footprint of 65 large and mid-sized US cities that also includes water used in products "imported" for urban consumption, indicating that the footprint is sub-linear in character (Mahjabin, Garcia, Grady, \& Mejia, 2018). To the best of our knowledge, this is a rare example. Unfortunately, not least because it would otherwise suggest that positive sustainability returns to scale could have been had, it goes against the grain of a vast array of case studies that suggest that while there are indeed gains to be had from increasing size, this is not necessarily true for all forms of consumption (Lerpold et al., 2020).

It should be noted, though, that in addition to the difficulties in measuring extra-urban impacts of urban consumption, there are other problems in using power laws and scaling, in particular, as indicators or phenomena are for the most part assessed one by one. Thus, Louf and Barthélémy (2014) suggest that if a prime negative externality that almost invariably increases with size, that of congestion, is taken into account, the results are often reversed. Other studies conducted at levels of considerable detail argue that there are good reasons to tread carefully and to avoid claims of universal validity (e.g. Arcaute et al., 2015; Cottineau, Hatna, Arcaute, \& Batty, 2017; Keuschnigg 2019; Pumain \& Rozenblat, 2019; Schiller, 2016). It is after all "particular industries, and 
commercial and industrial enterprises [...] and middle and upper income groups with high consumption lifestyles" (Mitlin \& Satterthwaite, 1996, 30) that account for most of the negative environmental impacts; it is their spatial distribution that matters. It thus boils down to what cities are used for and whom they attract. And as a corollary of the hierarchical spatial sorting observed, it would not come as a surprise if cities impose an environmental burden out of proportion.

There are a number of studies that suggest this is indeed the case. In addition to the claim by IPCC in its 2014 assessment report that there is a wide agreement that "a high proportion of global greenhouse gas emissions are generated by urban-based activities and residents" (Revi et al., 2015, 538), Folke, Jansson, Larsson and Costanza (1997) estimate that the overall "ecosystems appropriation" of 700+ major cities around the globe is higher than that of the rest of the world, that is, implying above average per capita impact from consumption in those cities. This is consistent with more recent work on megacities that notes that per capita consumption of energy, water and other resources are either in line with or higher than their populations would warrant, yet may well have smaller growth rates relative to urban GDP (Kennedy et al., 2015). Although not always unambiguous as to their empirical results, studies of urban metabolism also tend to find increasing per capita flows of energy and materials, both over time and with increasing size (e.g. Facchini et al., 2017; Kennedy, Cuddihy, \& Engel-Yan, 2007).

As for greenhouse gas emissions, many join Stern $(2007,517)$ in noting an out of proportion contribution of urban areas. Expressed differently, outsized CF appear to be spatially concentrated, with larger cities being over-represented. Although several of these cities are located in high $\mathrm{CF}$ countries and are reasonably in line with the national average, it is noticeable that large cities in low CF countries tend to be more similar to their counterparts in the former set of countries (Moran et al., 2018; compare the meta-study by Rybski et al., 2017). As is also true in studies on urban metabolism, the findings are not fully unambiguous, but on closer inspection studies such as Dodman (2009) that find cities to have a CF below what mere population size would suggest, often use production data (e.g. energy use in local transport and housing heating and cooling loads, as in Brown, Southworth, \& Sarzynski, 2009), as indeed one would expect of studies relying on the Global Protocol for Community-scale Greenhouse Gas Emission Inventories (Fong et al., 2014). Also, Satterthwaite $(2008,539)$, who argues that "the contribution of cities to global 
anthropogenic greenhouse gas emissions is often overstated", including as asserted in the Stern Report, suggests that many urban areas as sites of production or high-level consumption lifestyles do figure prominently in the statistics. To the extent that the pronounced carbon inequality found in many studies (Chancel \& Piketty, 2015; Hubacek et al., 2017; Ravallion, Heil, \& Jalan, 2000) reflect the impact of individuals living in major cities, these findings converge on the same realisation: unequal consumption and the differences in incomes that underpin it is key to addressing both environmental and at least parts of the social sustainability problems humankind faces.

The above critical observations clearly indicate that the social must be an important consideration in any attempt to understand developments; it cannot be reduced to environmental concerns (important as these are) or mere technical relationships. This is particularly so if it is to serve the end of formulating policy aimed at achieving sustainability. Thus, the ecological $\mathrm{E}$ of the 3 Es needs to be set in its societal context, while the other Es, like environmental, deserve to be taken seriously in their own right-and in combination. In this context it is worth noting that the allometric approach to assessing inter-urban differences does lend itself to studying social phenomena as well. Bettencourt, Lobo, Strumsky and West (2010) use this approach to examine per capita scaling of wealth (or income, rather), innovation (measured as patents) and (violent) crime across US cities, arriving at the conclusion that also for these phenomena the same type and magnitude of super-linearity is present. (For innovation, Bettencourt et al., 2007 appear to use a wider range of indicators, e.g. number of inventors, $R \& D$ establishments, private $R \& D$ employment, all super-linear in character, if to varying degrees.) That result is at least partly replicated by Hanley, Lewis and Haroldo (2016) for crime and for property transactions in England and Wales, even though some types of crimes were sub-linear in character (and those that were super-linear varied considerably as to their allometric exponent).

It is of course open to debate whether these represent the "meaningful urban metrics" necessary for policy that Bettencourt et al. (2010) call for; the very fact that the indicators used are arbitrary in the sense of not being derived from theory should give rise to reflection. This is especially so as when a richer set of indicators is being used (as in the British study), the outcomes vary quite considerably. Although such variation is most useful analytically, it serves to erode the point that larger or denser is better. Already a result suggesting that violent crime scales super-linearly at about 
the same rate as does innovation or income is a step in that direction, and we should perhaps start thinking about the sustainability trade-offs that probably are an inevitable characteristic of the urban condition.

As it happens, although there is no consensus as to such trade-offs, some results appear robust. In line with modelling efforts (e.g. Behrens \& Robert-Nicoud, 2014), empirically city size and density correlates with inequality: the larger the city, the more unequal it is (BaumSnow \& Pavan, 2014; Castells-Quintana, Royuela, \& Veneri, 2020; Combes, Duranton, Gobillon, \& Rouxe, 2012; Glaeser \& Gottlieb, 2009; Haworth, Long, \& Rasmussen, 1978; Stich, 1999). The precise sources of this pattern, however, are not equally well established. Wages (as a reflection of productivity differentials), land rents and capital gains from real estate in expanding urban areas are among the candidates. Others may include firm size, the level of affluence (higher levels correlating with higher inequality, see e.g. Lee, Sissons, \& Jones, 2016), and the effects of globalisation or the "new transnational economic geography" as Sassen $(1996,206)$ has it.

\section{Conclusion: The Need for Opening the Black Box of Urban Consumption and Production}

In short, we find two sets of empirical studies that arrive at distinctly different conclusions. At least in part, these differences can be put down to the data used and the assumption, prevalent in allometric studies, that population size alone is decisive. In turn, the inconclusive arguments over whether cities contribute more or less than their population numbers would suggest, underline the need to look at the contexts that individual urban systems afford. This includes the particulars of the various components of urban living, be it transportation, housing or demand for the countless types of consumer goods available in modern society. Add to this, as already noted, the specialisation across urban centres (including the "outsourcing" of negative externalities to other locations) and we find that impacts should also ideally be assessed by all consumption rather than by local production and local direct consumption alone. Taking a cue from Beck (2010) and other influential social theorists, this is equally relevant to social sustainability: the narrow focus implied by what we call "ontological cityism" should be replaced by one where global impacts are assessed-also as they might issue from individual localities or countries. 
This is all the more important as any rebound effects as might result from the savings implied by sub-linearity or the higher incomes that come with improved productivity are as likely as not to be registered well beyond the city boundary (Greening, Greene, \& Difiglio, 2000). Thus, by way of an example, while higher densities allow for better public transport, it does not follow that the number of private cars per capita necessarily are fewer or see less use. Pecuniary savings might translate into changes that serve to erode sustainability, as for instance energy savings effectively can be cancelled out as consumers avail themselves of "[t]urning lights into flights", as one study illuminatingly phrased it (Chitnis, Sorrell, Druckman, Firth, \& Jackson, 2013). Likewise, the better access to various amenities does not necessarily reduce the urge to fly off on weekend breaks to other major urban centres. Smaller and more expensive living quarters is not necessarily equivalent to less material spent on rebuilding or renovation. Nor, for that matter, does it imply a more equitable distribution of housing as such. Examples can be multiplied.

In the companion chapter (Lerpold et al., 2020), we turn our attention to issues of sustainability as they play out at the intra-urban level. Such an approach will not only allow for a more detailed picture, but also one that is potentially closer to the explanations sought for the variegated outcomes observed. It also allows for a closer look at social sustainability, an area of inquiry where the use of scaling laws appears less appropriate methodologically. As indicated by phenomena such as spatial sorting and differential productivity, it is not population size and density alone that set larger urban centres apart from the smaller ones or their surrounding countryside. Inequality, we have already noted, correlates with city size and density. This alone warrants that inter- and intra-urban effects are best approached in tandem. Add to this the potential environmental consequences of an inequitable distribution of resources and welfare both across and within cities, and it becomes clear that sustainable urban consumption and production is not quite as straightforward as a very visible part of the literature would have us believe.

Acknowledgements This contribution is based on research for the project "Urban sustainability, sustainably urban? The importance of interlocked markets to (un)sustainable outcomes in Stockholm and beyond", conducted under the auspices of the Center for Sustainability Research (CSR) of the Stockholm School of Economics Institute for Research (SIR). It is generously funded by the Marianne and Marcus Wallenberg Foundation (project MMW 2017.0060). The authors, Director of CSR and project director, respectively hereby gratefully acknowledge the support. 


\section{Note}

1. Note, though, that sorting over policies across local level jurisdictions-i.e. sorting in the Tiebout (1956) sense-is a distinctly different phenomenon that may well, as law and economics scholar Schleicher (2010: 1511) notes, "have an inverse relationship" with agglomeration effects.

\section{REFERENCES}

Angelo, H., \& Wachsmuth, D. (2015). Urbanizing urban political ecology: A critique of methodological cityism. International Journal of Urban and Regional Research, 39(1), 16-27.

Arcaute, E., Hatna, E., Ferguson, P., Youn, H., Johansson, A., \& Batty, M. (2015). Constructing cities, deconstructing scaling laws. Journal of the Royal Society Interface, 12(102), art. 20140745.

Barbier, E. B. (1987). The concept of sustainable economic development. Environmental Conservation, 14(2), 101-110.

Batty, M. (2013). The new science of cities. Cambridge, MA: MIT Press.

Batty, M. (2018). Inventing future cities. Cambridge, MA: MIT Press.

Baum-Snow, N., \& Pavan, R. (2014). Inequality and city size. Review of Economics and Statistics, 95(5), 1535-1548.

Beck, U. (2010). Remapping social inequalities in an age of climate change: For a cosmopolitan renewal of sociology. Global Networks, 10(2), 165-181.

Behrens, K., \& Robert-Nicoud, F. (2014). Survival of the fittest in cities: Urbanisation and inequality. Economic Journal, 124(581), 1371-1400.

Bettencourt, L. M. A. (2013). The origins and scaling of cities. Science, 340(6139), 1438-1441.

Bettencourt, L. M. A., \& Lobo, J. (2016). Urban scaling in Europe. Journal of the Royal Society Interface, 13(116), art. 20160005.

Bettencourt, L. M. A., Lobo, J., Helbing, D., Kühnert, C., \& West, G. B. (2007). Growth, innovation, scaling, and the pace of life in cities. Proceedings of the National Academy of Sciences of the United States of America, 104(17), 7301-7306.

Bettencourt, L. M. A., Lobo, J., Strumsky, D., \& West, G. B. (2010). Urban scaling and its deviations: Revealing the structure of wealth, innovation and crime across cities. PLoS One, 5(11), el3541.

Bettencourt, L. M. A., \& West, G. (2010). A unified theory of urban living. Nature, 467(7318), 912-913.

Bettencourt, L. M. A., \& West, G. B. (2011). Bigger cities do more with less: New science reveals why cities become more productive and efficient as they grow. Scientific American, 305(3), 44-45.

Bolton, K., \& Breau, S. (2012). Growing unequal? Changes in the distribution of warnings across Canadian cities. Urban Studies, 49(6), 1377-1396. 
Brown, M. A., Southworth, F., \& Sarzynski, A. (2009). The geography of carbon footprints. Policy and Society, 27(4), 285-304.

Campbell, S. D. (1996). Green cities, growing cities, just cities? Urban planning and the contradictions of sustainable development. Journal of the American Planning Association, 62(3), 296-312.

Campbell, S. D. (2016). The planner's triangle revisited: Sustainability and the evolution of a planning ideal that can't stand still. Journal of the American Planning Association, 82(4), 388-397.

Castells-Quintana, D., Royuela, V., \& Veneri, P. (2020). Inequality and city size: An analysis for OECD functional urban areas. Papers in Regional Science, 99(4), 1045-1064.

Chancel, L., \& Piketty, T. (2015). Carbon and inequality: From Kyoto to Paris. Trends in the global inequality of carbon emissions (1998-2013) \& prospects for an equitable adaptation fund. Paris: Paris School of Economics, November.

Chitnis, M., Sorrell, S., Druckman, A., Firth, S. K., \& Jackson, T. (2013). Turning lights into flights: estimating direct and indirect rebound effects for UK households. Energy Policy, 55(2013), 234-250.

Combes, P.-P., Duranton, G., Gobillon, L., \& Rouxe, S. (2012). Sorting and local wage and skill distributions in France. Regional Science and Urban Economics, 42(6), 913-930.

Combes, P.-P., \& Gobillon, L. (2015). The empirics of agglomeration economies. In G. Duranton, J. V. Henderson, \& W. C. Strange (Eds.), Handbook of regional and urban economics (Vol. 5, pp. 247-348). Amsterdam: North-Holland.

Cooney, G., Hawkins, T. R., \& Marriott, J. (2013). Life cycle assessment of diesel and electric public transportation buses. Journal of Industrial Ecology, 17(5), 689-699.

Cottineau, C., Hatna, E., Arcaute, E., \& Batty, M. (2017). Diverse cities or the systematic paradox of urban scaling laws. Computers, Environment and Urban Systems, 63, 80-94.

Dodman, D. (2009). Blaming cities for climate change? An analysis of urban greenhouse gas emissions inventories. Environment and Urbanization, 21(1), 185-201.

Dymitrow, M., \& Brauer, R. (2018). Meaningful yet useless? Factors behind the retention of questionable concepts in human geography. Geografiska Annaler: Series B, Human Geography, 100(2), 195-219.

Eeckhout, J., Pinheiro, R., \& Schmidheiny, K. (2014). Spatial sorting. Journal of Political Economy, 122(3), 554-620.

Facchini, A., Kennedy, C., Stewart, I., \& Mele, R. (2017). The energy metabolism of megacities. Applied Energy, 186(2), 86-95.

Fallah, B. N., Partridge, M. D., \& Olfert, M. R. (2011). New economic geography and US metropolitan wage inequality. Journal of Economic Geography, 11(5), 865-895. 
Folke, C., Jansson, A., Larsson, J., \& Costanza, R. (1997). Ecosystems appropriation by cities. Ambio, 26(3), 167-172.

Fong, W. K., Sotos, M., Doust, M., Schultz, S., Marques, A., \& Deng-Beck, C. (2014). Global protocol for community-scale greenhouse gas emission inventories: An accounting and reporting standard for cities. Washington, DC: World Resources Institute/CR Cities Climate Leadership Group/ICLEILocal Governments for Sustainability.

Glaeser, E. L. (2011). Triumph of the city: How our greatest invention makes us richer, smarter, greener, healthier, and happier. Harmondsworth: Penguin.

Glaeser, E. L., \& Gottlieb, J. D. (2009). The wealth of cities: Agglomeration economies and spatial equilibrium in the United States. Journal of Economic Literature, 47(4), 983-1028.

Glaeser, E. L., Resseger, M., \& Tobia, K. (2009). Inequality in cities. Journal of Regional Science, 49(4), 617-646.

Glaeser, E. L., \& Resseger, M. R. (2010). The complementarity between cities and skills. Journal of Regional Science, 50(1), 221-244.

Godschalk, D. R. (2004). Land use planning challenges: Coping with conflicts in visions of sustainable development and liveable communities. Journal of the American Planning Association, 70(1), 5-13.

Gontia, P., Thuvander, L., \& Wallbaum, H. (2020). Spatiotemporal characteristics of residential material stocks and flows in urban, commuter, and rural settlements. Journal of Cleaner Production, 251, art. 119435.

Greening, L. A., Greene, D. L., \& Difiglio, C. (2000). Energy efficiency and consumption-The rebound effect-A survey. Energy Policy, 28(6-7), 389401 .

Haavelmo, T., \& Hansen, S. (1992). On the strategy of trying to reduce economic inequality by expanding the scale of human activity. In R. Goodland, H. E. Daly, \& S. E. Serafy (Eds.), Population, technology, and lifestyle: The transition to sustainability (pp. 38-51). Washington, DC: Island Press.

Hanley, Q. S., Lewis, D., \& Haroldo, H. V. (2016). Rural to urban population density scaling of crime and property transactions in English and Welsh Parliamentary Constituencies. PLoS One, 11(12), e0167605.

Hanson, G. H. (2001). Scale economies and the geographic concentration of industry. Journal of Economic Geography, 1(3), 255-276.

Haworth, C. T., Long, J. E., \& Rasmussen, D. W. (1978). Income distribution, city size, and urban growth. Urban Studies, 15(1), 1-7.

Hirt, S. A. (2016). The city sustainable: Three thoughts on "Green cities, growing cities, just cities". Journal of the American Planning Association, $82(4), 383-384$.

Hoover, E. M. (1937). Location theory and the shoe and leather industries. Cambridge, MA: Harvard University Press. 
Hubacek, K., Baiocchi, G., Feng, K., Castillo, R. M., Sun, L., \& Xue, J. (2017). Global carbon inequality. Energy, Ecology and Environment, 2(6), 361-369.

Jacobs, J. (1969). The economy of cities. New York: Random House.

Joss, S. Cowley, R., Jong, M. D., Müller, B., Park, B. S., Rees, W., ... Rydin, Y. (2015). Tomorrow's city today: Prospects for standardising sustainable urban development. London: University of Westminster.

Kennedy, C., Cuddihy, J., \& Engel-Yan, J. (2007). The changing metabolism of cities. Journal of Industrial Ecology, 11(2), 43-59.

Kennedy, C. A., Stewart, I., Facchini, A., Cersosimo, I., Mele, R., Chen, B., ... Sahin, A. D. (2015). Energy and material flows of megacities. Proceedings of the National Academy of Sciences of the United States of America, 112(19): 5985-5990.

Keuschnigg, M. (2019). Scaling trajectories of cities. Proceedings of the National Academy of Sciences of the United States of America, 116(29), 13759-13761.

Korpi, M. (2008). Does size of local labour markets affect wage inequality? A rank-size rule of income distribution. Journal of Economic Geography, 8(2), 211-237.

Larco, N. (2016). Sustainable urban design-A (draft) framework. Journal of Urban Design, 21(1), 1-29.

Lee, N., Sissons, P., \& Jones, K. (2016). The geography of wage inequality in British cities. Regional Studies, 50(10), 1714-1727.

Lerpold, L., Sjöberg, Ö., \& Tang, W.-S. (2020). Urban advantage? Sustainability trade-offs across and within intra-urban space. In R. Bali Swain \& S. Sweet (Eds.), Sustainable consumption and production, Volume 1: Challenges and development. London: Palgrave Macmillan.

Louf, R., \& Barthélémy, M. (2014). How congestion shapes cities: From mobility patterns to scaling. Scientific Reports, 4, art. 5561.

Louf, R., Roth, C., \& Barthélémy, M. (2014). Scaling in transportation networks. PLoS One, 9(7), e102007.

Mahjabin, T., Garcia, S., Grady, C., \& Mejia, A. (2018). Large cities get more for less: Water footprint efficiency across the US. PLoS One, 13(8), e0202301.

Marshall, A. (1890). Principles of economics: An introductory volume. London: Macmillan.

Miller, B. (2015). Sustainability for whom? Sustainability how? In D. Wilson (Ed.), The politics of the urban sustainability concept (pp. 107-116). Champaign, IL: Common Ground.

Mion, G., \& Naticchioni, P. (2009). The spatial sorting and matching of skills and firms. Canadian Journal of Economics/Revue canadienne d'économique, $42(1), 28-55$.

Mitlin, D., \& Satterthwaite, D. (1996). Sustainable development and cities. In C. Pugh (Ed.), Sustainability, the environment and urbanization (pp. 23-61). London: Earthscan. 
Moran, D., Kanemoto, K., Jiborn, M., Wood, R., Többen, J., \& Seto, K. C. (2018). Carbon footprints of 13000 cities. Environmental Research Letters, 13(6), art. 064041.

Moriarty, B. M. (1991). Urban systems, industrial restructuring, and the spatial-temporal diffusions of manufacturing employment. Environment and Planning, A, 23(11), 1571-1588.

Næss, P. (2001). Urban planning and sustainable development. European Planning Studies, 9(4), 503-524.

Newton, P. W. (2011). Consumption and environmental sustainability. In P. W. Newton (Ed.), Urban consumption (pp. 1-25). Collingwood, VIC: CSIRO.

Nordbeck, S. (1971). Urban allometric growth. Geografiska Annaler: Series B, Human Geography, 53(1), 54-67.

Puga, D. (2010). The magnitudes and causes of agglomeration economies. Journal of Regional Science, 50(1), 203-219.

Pumain, D. (2012). Urban systems dynamics, urban growth and scaling laws: The question of egodicity. In J. Portugali, H. Meyer, E. Stolk, \& E. Tan (Eds.), Complexity theories of cities have come of age: An overview with implications to urban planning and design (pp. 91-103). Heidelberg: Springer-Verlag.

Pumain, D., Paulus, F., Vacchiani-Marcuzzo, C., \& Lobo, J. (2006). An evolutionary theory for interpreting urban scaling laws. Cybergeo, 343 [online]. URL http://journals.openedition.org/cybergeo/2519. Accessed 18 December 2019.

Pumain, D., \& Rozenblat, C. (2019). Two metropolisation gradients in the European system of cities revealed by scaling laws. Environment and Planning B: Urban Analytics and City Science, 46(9), 1645-1662.

Purvis, B., Mao, Y., \& Robinson, D. (2019). Three pillars of sustainability: In search of conceptual origins. Sustainability Science, 14(3), 681-695.

Ravallion, M., Heil, M., \& Jalan, J. (2000). Carbon emissions and income inequality. Oxford Economic Papers, 52(4), 651-669.

Rees, W. E., \& Wackernagel, M. (1996). Urban ecological footprints: Why cities cannot be sustainable-And why they are key to sustainability. Environmental Impact Assessment Review, 16(4-6), 223-248.

Rees, W. E. (1992). Ecological footprints and appropriated carrying capacity: What urban economics leaves out. Environment and Urbanization, 4(2), 121-130.

Rees, W. E. (2012). Cities as dissipative structures: Global change and the vulnerability of urban civilization. In M. P. Weinstein \& R. E. Turner (Eds.), Sustainability science: The emerging paradigm and the urban environment (pp. 247-273). New York: Springer.

Revi, A., Satterthwaite, D. E., Aragón-Durand, F., Corfee-Morlot, J., Kiunsi, R. B. R., Pelling, M., ... White, L. L. (Eds.). (2014). Climate change 2014Impacts, adaptation, and vulnerability. Part A: Global and sectoral aspects. 
Contribution of working group II to the Fifth Assessment Report of the Intergovernmental Panel on Climate Change (pp. 535-612). New York: Cambridge University Press.

Rigby, D. L., \& Essletzbichler, J. (2002). Agglomeration economies and productivity differences in US cities. Journal of Economic Geography, 2(4), 407-432.

Rybski, D., Reusser, D. E., Winz, A.-L., Fichtner, C., Strezel, T., \& Kropp, J. P. (2017). Cities as nuclei of sustainability? Environment and Planning B: Urban Analytics and City Science, 44(3), 425-440.

Sassen, S. (1996). Whose city is it? Globalization and the formation of new claims. Public Culture, 8(2), 205-223.

Satterthwaite, D. (1997). Sustainable cities or cities that contribute to sustainable development. Urban Studies, 34(10), 1667-1691.

Satterthwaite, D. (2008). Cities' contribution to global warming: Notes on the allocation of greenhouse gas emissions. Environment and Urbanization, 20(2), 539-549.

SCB. (2019). Environmental pressure from consumption-New official statistics. Stockholm [online]: Statistics Sweden. URL https://www.scb.se/en/fin ding-statistics/statistics-by-subject-area/environment/environmental-acc ounts-and-sustainable-development/system-of-environmental-and-economicaccounts/pong/statistical-news/environmental-accounts-environmental-pre ssure-from-consumption-2017/. Accessed 19 December 2019.

Schiller, F. (2016). Urban transitions: Scaling complex cities down to human size. Journal of Cleaner Production, 112(5), 4273-4282.

Schleicher, D. (2010). The city as a law and economics subject. University of Illinois Law Review, 5, 1507-1563.

Scott, A. J., \& Storper, M. (2014). The nature of cities: The scope and limits of urban theory. International Journal of Urban and Regional Research, 39(1), $1-15$.

Seto, K. C., Reenberg, A., Boone, C. G., Fragkias, M., Haase, D., Langanke, T., ... Simon, D. (2012). Urban land teleconnections and sustainability. Proceedings of the National Academy of Sciences of the United States of America, $100(15), 7687-7692$.

Stern, N. (2007). The economics of climate change: The Stern review. Cambridge: Cambridge University Press.

Stich, A. (1999). On rich cities and boring places. Urban Studies, 36(10), 16491660.

Storper, M., \& Venables, A. J. (2004). Buzz: Face-to-face contact and the urban economy. Journal of Economic Geography, 4(4), 351-370.

Sveikauskas, L. (1975). The productivity of cities. Quarterly Journal of Economics, $89(3), 393-413$.

Thisse, J.-F. (2014). The new science of cities by Michael Batty: The opinion of an economist. Journal of Economic Literature, 52(3), 805-819. 
Tiebout, C. M. (1956). A pure theory of local expenditures. Journal of Political Economy, 64(5), 416-424.

Venables, A. J. (2011). Productivity in cities: Self-selection and sorting. Journal of Economic Geography, 11(2), 241-251.

West, G. B. (2017). Scale: The universal laws of growth, innovation, sustainability, and the pace of life in organisms, cities, economies, and companies. New York: Penguin.

Wheeler, C. H. (2001). Search, sorting, and urban agglomeration. Journal of Labor Economics, 19(4), 879-899.

Wheeler, C. H. (2004). Wage inequality and urban density. Journal of Economic Geography, 4(4), 421-437.

Wimmer, A., \& Glick Schiller, N. (2002). Methodological nationalism and beyond: Nation-state building, migration and the social sciences. Global Networks, 2(4), 301-334.

Youn, H., Bettencourt, L. M. A., Lobo, J., Strumsky, D., Samaniego, H., \& West, G. B. (2016). Scaling and universality in urban economic diversification. Journal of the Royal Society Interface, 13(114), art. 20150937.

Zheng, B., de Beurs, K. M., Owsley, B. C., \& Henebry, G. M. (2019). Scaling relationship between CO pollution and population size over major US metropolitan statistical areas. Landscape and Urban Planning, 187, 191-198.

Open Access This chapter is licensed under the terms of the Creative Commons Attribution 4.0 International License (http://creativecommons.org/licenses/ by $/ 4.0 /$ ), which permits use, sharing, adaptation, distribution and reproduction in any medium or format, as long as you give appropriate credit to the original author(s) and the source, provide a link to the Creative Commons licence and indicate if changes were made.

The images or other third party material in this chapter are included in the chapter's Creative Commons licence, unless indicated otherwise in a credit line to the material. If material is not included in the chapter's Creative Commons licence and your intended use is not permitted by statutory regulation or exceeds the permitted use, you will need to obtain permission directly from the copyright holder.

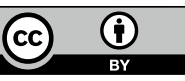

